\title{
Mechanical Circulatory Support as a Bridge to Recovery in Fulminant Myocarditis
}

\author{
Yassir lqbal", Saifullah Mohammed, Aaron Ranasinghe \\ From World Society of Cardiothoracic Surgeons 25th Anniversary Congress, Edinburgh \\ Edinburgh, UK. 19-22 September 2015
}

\section{Background/Introduction}

Ventricular assist devices have been routinely used in patients with end stage heart failure as a bridge to transplantation. We present a case of using a Bi-Ventricular Assist Device (BiVAD) in a patient with fulminant heart failure as a bridge to recovery.

\section{Aims/Objectives}

A 36 year old lady with a history of Grave's Disease and three months post-partum presented with fulminant myocarditis.

She presented to her local hospital on 2nd January with episodes of ventricular tachycardia (VT) and syncope. She was transferred to a tertiary level cardiology centre as she failed to cardiovert. Echocardiography demonstrated significant left ventricular (LV) thickening and LV stasis. She continued to have VT storms and was referred to our advanced heart failure service.

\section{Method}

On arrival she rapidly deteriorated with recurrent VT and ventricular fibrillation (VF) episodes causing severe haemodynamic compromise. A decision was made to institute mechanical circulatory support with venoarterial Extra-Corporeal Membrane Oxygenation (VAECMO). During cardiopulmonary resuscitation she was placed onto VA-ECMO and stabilised. That same evening she underwent conversion to BiVAD support for offloading of both ventricles.

\section{Results}

She was extubated on the first post-operative day. Myocardial biopsy performed during BiVAD implantation confirmed florid myocarditis.

\footnotetext{
Department of Cardiac Surgery, Queen Elizabeth Hospital, Birmingham, B15
} 2TH, UK

\section{and take full advantage of:}

- Convenient online submission

- Thorough peer review

- No space constraints or color figure charges

- Immediate publication on acceptance

- Inclusion in PubMed, CAS, Scopus and Google Scholar

- Research which is freely available for redistribution

Submit your manuscript at 